\title{
First-line gemcitabine with cisplatin or epirubicin in advanced non-small-cell lung cancer: a phase III trial
}

\section{FM Wachters', JWG van Putten', H Kramer', Z Erjavec ${ }^{2}$, P Eppinga $^{3}$, JH Strijbos $^{3}$, GPJ de Leede ${ }^{4}$, HM Boezen $^{5}$, EGE de Vries ${ }^{6}$ and HJM Groen*,i}

'Department of Pulmonary Diseases, University Hospital Groningen, PO Box 30.001, 9700 RB Groningen, The Netherlands; ${ }^{2}$ Department of Internal Medicine, Delfzicht Hospital, Jachtlaan 50, 9934 JD Delfzijl, The Netherlands; ${ }^{3}$ Department of Pulmonary Diseases, Nij Smellinghe Hospital, Compagnonsplein I, 9202 NN Drachten, The Netherlands; ${ }^{4}$ Department of Pulmonary Diseases, Bethesda Hospital, Amshoffweg I, 7909 AA

Hoogeveen, The Netherlands; ${ }^{5}$ Department of Epidemiology and Statistics, University of Groningen, Antonius Deusinglaan I, 9713 AV Groningen, The Netherlands; 'Department of Medical Oncology, University Hospital Groningen, PO Box 30.001, 9700 RB Groningen, The Netherlands

The purpose of our study was to compare progression-free survival and quality of life (QOL) after cisplatin-gemcitabine (CG) or epirubicin-gemcitabine (EG) in chemotherapy-naive patients with unresectable non-small-cell lung cancer. Patients $(n=240)$ were randomised to receive gemcitabine $1125 \mathrm{mg} \mathrm{m}^{-2}$ (days I and 8) plus either cisplatin $80 \mathrm{mg} \mathrm{m}^{-2}$ (day 2) or epirubicin $100 \mathrm{mg} \mathrm{m}^{-2}$ (day I) every 3 weeks for a maximum of five cycles. Eligible patients had normal organ functions and Eastern Cooperative Oncology Group performance status $\leqslant 2$. QOL was measured with European Organisation for Research and Treatment of Cancer QLQ-C30 and LCI 3 questionnaires. There were no significant differences in median progression-free survival (CG 26 weeks, EG 23 weeks), median overall survival (CG 43 weeks, EG 36 weeks), or tumour response rates (CG 46\%, EG 36\%). Toxicity was mainly haematologic. In the EG arm granulocytopenia occurred more frequently, leading to more febrile neutropenia. Also, elevation of serum transaminases, mucositis, fever, and decline in LVEF were more common in the EG arm. In the CG arm, more patients experienced elevated serum creatinine levels, sensory neuropathy, nausea, and vomiting. Global QOL was not different in both arms. Progression-free survival, overall survival, response rate, and QOL were not different between both arms; however, overall toxicity was more severe in the EG arm.

British Journal of Cancer (2003) 89, I 192- | 199. doi:I0.1038/sj.bjc.660 I 283 www.bjcancer.com (c) 2003 Cancer Research UK

Keywords: non-small-cell lung cancer; cisplatin; epirubicin; gemcitabine; phase III trial; chemotherapy

Platinum-based chemotherapy is the standard treatment for patients with advanced non-small-cell lung cancer (NSCLC) who have a good performance status (American Society of Clinical Oncology, 1997). A meta-analysis published in 1995 showed that cisplatin-based chemotherapy induces $27 \%$ reduction in the risk of death, $10 \%$ improvement in survival at 1 year, and an absolute increase in median survival of 1.5 months compared to best supportive care (Non-small Cell Lung Cancer Collaborative Group, 1995). Since then, several new chemotherapeutic agents in combination with platinum have been investigated for their beneficial effect in patients with NSCLC. Phase II studies of new drugs in combination with platinum, published between 1992 and 1997 and reviewed by Bunn and Kelly, showed a prolonged survival from about 4 to 10 months, a prolonged 1-year survival rate from 10 to $40-50 \%$, and an improved quality of life (QOL) (Bunn and Kelly, 1998).

In spite of the fact that cisplatin-containing regimens are currently considered the treatment of choice for advanced NSCLC, cisplatin has several disadvantages such as nephro-, neuro-, and ototoxicity. Therefore, nonplatinum-containing regimens have been studied to find less toxic therapies with similar efficacy.

*Correspondence: Dr HJM Groen; E-mail: h.j.m.groen@int.azg.nl Received 6 March 2003; revised 30 June 2003; accepted 21 July 2003
Phase III studies have reported similar response rates and overall survival in cisplatin and noncisplatin-based regimens. However, in the majority of these trials the nonplatinum regimens had a more favourable toxicity profile (Gatzemeier et al, 1991; Gridelli et al, 1996; Georgoulias et al, 2001; Kosmidis et al, 2002; Sculier et al, 2002).

Gemcitabine, a nucleoside analogue, has shown activity against NSCLC as a single agent. Phase II studies showed response rates between $18-26 \%$ and a mild toxicity profile (Anderson et al, 1994; Gatzemeier et al, 1996; Halme et al, 1997; Yokoyama et al, 1997; Perng et al, 1997; Takada et al, 1998; Zatloukal et al, 1998; Ten Bokkel Huinink et al, 1999). The combination of cisplatin and gemcitabine in NSCLC has been evaluated in phase III trials, reporting response rates of $22-41 \%$ and median survival between 8.1 and 9.7 months (Cardenal et al, 1999; Crino et al, 1999; Comella et al, 2000; Sandler et al, 2000; Schiller et al, 2002).

As a single-agent epirubicin, the $4^{\prime}$ epimer of the anthracycline antibiotic doxorubicin, showed tumour response rates from 17 up to $36 \%$ in NSCLC (Wils et al, 1990; Feld et al, 1992; Smit et al, 1992). The main toxicities of epirubicin are myelosuppression, mucositis, and cardiomyopathy (Wils et al, 1990; Feld et al, 1992; Smit et al, 1992). In our institution, the activity of epirubicin combined with gemcitabine was studied in phases I and II study (Van Putten et al, 2000). In this trial, a dose of $1125 \mathrm{mg} \mathrm{m}^{-2}$ gemcitabine on days 1 and 8 of each 21-day cycle was chosen since 
this dose leads to a dose intensity of $750 \mathrm{mg} \mathrm{m}^{-2}$ week $^{-1}$, which is similar as the schedule in which single-agent gemcitabine $1000 \mathrm{mg} \mathrm{m}^{-2}$ is given weekly for 3 consecutive weeks in a 28 -day schedule. The nadir of epirubicin is expected $12-15$ days after administration; therefore, gemcitabine was omitted on day 15 . The phase II trial continued with a dose of $100 \mathrm{mg} \mathrm{m}^{-2}$ epirubicin because in the preceeding phase I dose-escalation trial, a maximum tolerated dose of $120 \mathrm{mg} \mathrm{m}^{-2}$ was reached. The haematologic toxicity of this regimen was acceptable with granulocytopenia grade 4 in 33\% and thrombocytopenia grade 4 in $12 \%$ of the cycles. Febrile neutropenia occurred in $14 \%$ of patients. Nonhaematologic toxicity was mainly mucositis grade 2 and 3 in 35\% of patients. Cardiotoxicity measured as a significant decrease of left-ventricular ejection fraction (LVEF) was observed in $7 \%$ of patients. The tumour response rate was $49 \%$ and the median survival time was 42 weeks (Van Putten et al, 2000).

Manageable toxicity and high response rates of the epirubicingemcitabine regimen were the background for initiating this phase III trial. The aim of this phase III trial was to compare the efficacy and safety of gemcitabine in combination with either cisplatin (standard arm) or epirubicin. Epirubicin in combination with gemcitabine (EG) was administered as an outpatient regimen, the cisplatin-gemcitabine (CG) combination was given as a short inpatient regimen as is often done in European countries. The American Society of Clinical Oncology guidelines (published in 1997) recommended two to eight cycles of platinum-based treatment in advanced NSCLC. We chose a maximum of five cycles. Progression-free survival was the primary end point of the study. Overall survival, response rate, toxicity, and QOL were secondary end points.

\section{PATIENTS AND METHODS}

\section{Patient selection}

Patients were included if they had histological or cytological diagnosis of unresectable stage III or stage IV NSCLC and at least one measurable or evaluable tumour lesion on physical examination, chest X-ray, or chest CT. No prior chemotherapy was allowed and radiotherapy was permitted as long as no more than $25 \%$ of the bone marrow was irradiated. Radiotherapy should have been completed at least 4 weeks before inclusion, and patients should have recovered from any toxic side effect. The irradiated area was excluded from tumour measurements. All patients had to have a performance status $\leqslant 2$ according to the Eastern Cooperative Oncology Group (ECOG) scale and a life expectancy of at least 12 weeks. An adequate bone marrow reserve (leucocytes $\geqslant 3.0 \times 10^{9} 1^{-1}$, neutrophils $\geqslant 1.5 \times 10^{9} 1^{-1}$, platelets $\geqslant 100 \times 10^{9} \mathrm{l}^{-1}$, haemoglobin $\geqslant 6.2 \mathrm{mmoll}^{-1}$ ), normal renal (serum creatinine $\leqslant 120 \mu \mathrm{moll}^{-1}$ or creatinine clearance $\geqslant 60 \mathrm{ml} \mathrm{min}^{-1}$ ) and liver function (serum bilirubin $\leqslant 35 \mu \mathrm{moll}^{-1}$, serum alanine aminotransferase (ALAT), and serum aspartate aminotransferase (ASAT) less than three times the upper limit of normal) were required. Patients were excluded if they had active infections, second primary malignancies (except carcinoma in situ of the cervix, adequately treated basal cell carcinoma of the skin, and adequately treated upper respiratory tract malignancy), uncorrected hypercalcaemia, or an LVEF $\leqslant 45 \%$ measured by multiple gated acquisition (MUGA) scan. Local medical ethics committees of all hospitals approved the protocol. All patients gave informed consent before study entry.

\section{Treatment}

Eligible patients were randomised by telephone to receive either cisplatin or epirubicin both with gemcitabine. Gemcitabine $\left(1125 \mathrm{mg} \mathrm{m}^{-2}\right)$ was administered in $250 \mathrm{ml} 0.9 \% \mathrm{NaCl}$ by a
30 min infusion on days 1 (before cisplatin or epirubicin) and 8. Cisplatin $80 \mathrm{mg} \mathrm{m}^{-2}$ (in $1000 \mathrm{ml} 0.9 \% \mathrm{NaCl}$ ) was administered intravenously during $3 \mathrm{~h}$ after prehydration with $0.9 \% \mathrm{NaCl}$ on day 2 of each 21-day treatment cycle. Epirubicin $100 \mathrm{mg} \mathrm{m}^{-2}$ (in $50 \mathrm{ml}$ $0.9 \% \mathrm{NaCl}$ ) was administered as an intravenous bolus injection within $5 \mathrm{~min}$ on day 1 of each 21-day cycle. For prehydration, patients in the CG arm were admitted to hospital for 2 days. Epirubicin-gemcitabine was administered as an outpatient regimen. Anti-emetics consisted of ondansetron $8 \mathrm{mg}$ and dexamethasone $8 \mathrm{mg}$ twice a day on days 1,2 , and 8 . The treatment consisted of a maximum of five cycles and was stopped earlier in case of tumour progression, intolerable toxicity, or patient's wish. No treatment with G-CSF was foreseen. In case of $\mathrm{Hb}<5.0 \mathrm{mmoll}^{-1}$ or symptomatic anaemia in combination with $\mathrm{Hb}<6.0 \mathrm{mmoll}$, patients were treated with red blood cell transfusion. Platelet transfusion was given in the event of platelets $<10 \times 10^{9} 1^{-1}$ or persistent bleeding in combination with platelets $<20 \times 10^{9} 1^{-1}$.

\section{Dose adjustments}

Drug administration was postponed to a maximum of 2 weeks if there was no haematologic recovery on day 22 (neutrophils $<1.5 \times 10^{9} 1^{-1}$ and/or platelets $<100 \times 10^{9} 1^{-1}$ ) or in case of persistent common toxicity criteria (CTC) grade 2 or more nonhaematologic toxicity (except alopecia). The dose of cisplatin or epirubicin for subsequent cycles was reduced to $75 \%$ in case of a nadir of neutrophils below $0.5 \times 10^{9} 1^{-1}$ exceeding 7 days, a nadir of platelets below $25 \times 10^{9} 1^{-1}$, thrombocytopenia associated with bleeding, febrile neutropenia, or CTC grade 3 nonhaematologic toxicity (except nausea and vomiting). The cisplatin dose was reduced by $50 \%$ for a calculated creatinine clearance between 50 and $70 \mathrm{ml} \mathrm{min}^{-1}$, and in case of a creatinine clearance less than $50 \mathrm{ml} \mathrm{min}^{-1}$ cisplatin was not administered (Cockcroft and Gault, 1976). The dose of gemcitabine on day 8 was reduced to $50 \%$ in case of neutrophils between 0.5 and $1.5 \times 10^{9} 1^{-1}$, platelets between 50 and $100 \times 10^{9} 1^{-1}$ or grade 3 nonhaematologic toxicity on day 8 . Gemcitabine was omitted on day 8 in case of neutrophils $<0.5 \times 10^{9} 1^{-1}$, platelets $<50 \times 10^{9} 1^{-1}$ or grade 4 nonhaematologic toxicity. The mean relative dose intensity was calculated by dividing the delivered dose $\left(\mathrm{mg} \mathrm{m}^{-2}\right.$ week $\left.{ }^{-1}\right)$ by the planned dose $\left(\mathrm{mg} \mathrm{m}^{-2}\right.$ week $\left.^{-1}\right)$ for the number of cycles each patient received.

\section{Treatment evaluation}

Complete blood cell counts were performed at least on days 1 and 8 of each cycle. On day 1 of each cycle, patient evaluation also included liver and renal functions, performance status, and toxicity scoring according to the CTC of the National Cancer Institute. The LVEF was measured by the MUGA scan before and 6-12 weeks after treatment. All patients were evaluable for toxicity. The tumour response was evaluated by the treating physician, at least after three and five cycles, according to the World Health Organisation (WHO) criteria (WHO, 1979). After treatment, tumour responses were evaluated by an independent observer.

After discontinuation of treatment, patients were evaluated every 6 weeks with physical examination, laboratory tests, chest Xray or CT-scan of the chest, and additional imaging tests on clinical indication to assess tumour progression.

At the start of treatment, after three cycles of chemotherapy, and 6 weeks after the end of treatment, QOL was measured with the European Organisation for Research and Treatment of Cancer (EORTC) QLQ-C30, supplemented by a 13-item lung-cancerspecific questionnaire module, the EORTC QLQ-LC13. This validated questionnaire was filled in at home and is composed of a core QOL questionnaire covering general aspects of healthrelated QOL and disease- and treatment-specific symptoms (Aaronson et al, 1993; Bergman et al, 1994). 


\section{Statistical analysis}

The primary end point of the study was progression-free survival. The study was designed to detect a $20 \%$ increase in 6-month progression-free survival, from $40 \%$ in the CG arm to $60 \%$ in the EG arm. To detect such an increase using a two-sided 0.05 alpha-level test with $85 \%$ power, the required accrual was determined to be 120 patients in both arms. Analysis was performed on the intention-to-treat principle. The time from the date of randomisation to the date of first documented progression was defined as progression-free survival. Overall survival was defined as the interval between the date of randomisation to the date of death. Progression-free and overall survivals for both treatment arms were compared by KaplanMeier curves using the log-rank test. Quality of life was analysed by ANOVA for the different functional areas and symptoms at all three points of measurement. To identify potential prognostic factors, a multivariate analysis was performed using a logistic regression model for response rate and a Cox regression model for progression-free and overall survivals. A $P<0.05$ was considered statistically significant.

\section{RESULTS}

\section{Patient characteristics}

Between November 1998 and February 2002, 240 patients from four hospitals in the Northern part of the Netherlands were recruited. Patients were randomised to CG $(n=119)$ or EG $(n=121)$. Patient characteristics were not significantly different between both treatment arms (Table 1). Seven patients had been treated with prior radiotherapy on the primary tumour. Three randomised patients did not receive chemotherapy because of rapidly deteriorating performance status due to progression of disease before treatment initiation. These patients were included in all analyses.

\section{Toxicity}

Haematologic toxicity is shown in Table 2. In the EG arm, grade 3 or 4 leukopenia and granulocytopenia occurred more frequently as compared to the CG arm. Epirubicin-gemcitabine patients were more often hospitalised for febrile neutropenia than patients in the CG arm (11 vs $2 \%$ of patients, $P=0.006$ ). In both arms, two patients died due to septicaemia (EG arm after one and three cycles, CG arm after three and five cycles). In the CG arm, 56\% of patients had one or more red blood cell transfusions during treatment, compared to $51 \%$ of patients in the EG arm $(P=0.433)$. At the time of study, erythropoietin was not routinely administered. The number of red blood cell transfusions per patient was also not different between both treatment arms.

The worst nonhaematologic toxicity per patient is listed in Table 3. Gemcitabine can induce short-lasting elevation of transaminases, this was experienced more frequently in the EG arm $(P=0.001)$. Patients in the EG arm also had more often short-lasting fever (in the absence of neutropenia). Nausea, vomiting, and fatigue frequently occurred in both arms, but more often in the CG arm. Significantly more patients in the EG arm had a grade 1 (16\% in the CG arm vs $42 \%$ in the EG arm) and grade 2 (7\% in the CG arm $v s 13 \%$ in the EG arm) decline in LVEF $(P=0.006, n=69)$. Clinically evident cardiac failure was not observed during follow-up. In this trial, 28 elderly patients $(\geqslant 70$ years) were included. In these patients, grade 3 or 4 thrombocytopenia occurred more frequently compared to younger patients, in $78 v s 46 \%$ of patients, respectively $(P=0.029)$. No differences in other toxicities were found when comparing them to younger patients.
Table I Patient characteristics

\begin{tabular}{|c|c|c|c|c|c|}
\hline & \multicolumn{2}{|c|}{ Cisplatin-gemcitabine } & \multicolumn{2}{|c|}{ Epirubicin-gemcitabine } & \multirow[b]{2}{*}{$P$} \\
\hline & No. & $\%$ & No. & $\%$ & \\
\hline Patients entered & 119 & 50 & 121 & 50 & ns \\
\hline Sex & & & & & ns \\
\hline Male & 94 & 79 & 85 & 70 & \\
\hline Female & 25 & 21 & 36 & 30 & \\
\hline \multicolumn{6}{|l|}{ Age, years } \\
\hline Median & 60 & & 60 & & \\
\hline Range & $29-80$ & & $32-76$ & & ns \\
\hline \multicolumn{5}{|l|}{ Stage } & ns \\
\hline Illa & 8 & 7 & 8 & 7 & \\
\hline$\| l l b$ & 43 & 36 & 44 & 36 & \\
\hline IV & 68 & 57 & 69 & 57 & \\
\hline \multicolumn{5}{|l|}{ Performance status } & ns \\
\hline 0 & 36 & 30 & 37 & 31 & \\
\hline 1 & 66 & 55 & 73 & 60 & \\
\hline 2 & 17 & 14 & 11 & 9 & \\
\hline \multicolumn{5}{|l|}{ Histology } & ns \\
\hline Squamous cell carinoma & 41 & 35 & 32 & 26 & \\
\hline Adenocarcinoma & 41 & 35 & 50 & 41 & \\
\hline Large cell carcinoma & 36 & 30 & 38 & 31 & \\
\hline Other & । & 1 & । & I & \\
\hline \multicolumn{5}{|l|}{ Weight loss (last 3 months) } & ns \\
\hline$<5 \%$ & 82 & 69 & 80 & 66 & \\
\hline$\geqslant 5 \%$ & 37 & 31 & 41 & 34 & \\
\hline \multicolumn{5}{|l|}{ Liver metastases } & ns \\
\hline Absent & 109 & 92 & 111 & 92 & \\
\hline Present & 10 & 8 & 10 & 8 & \\
\hline
\end{tabular}

$\mathrm{ns}=$ Not significant.

Table 2 Worst haematologic CTC toxicity grade per patient

\begin{tabular}{|c|c|c|c|c|c|}
\hline \multirow[b]{2}{*}{ Toxicity } & \multicolumn{2}{|c|}{ Cisplatin-gemcitabine } & \multicolumn{2}{|c|}{ Epirubicin-gemcitabine } & \multirow[b]{2}{*}{$P$} \\
\hline & No. & $\%$ & No. & $\%$ & \\
\hline Anaemia & & & & & ns \\
\hline 1 & 20 & 17 & 18 & 16 & \\
\hline 2 & 77 & 66 & 68 & 60 & \\
\hline $3 / 4$ & 20 & 17 & 26 & 23 & \\
\hline Leukopenia & & & & & $<0.01$ \\
\hline 1 & 24 & 21 & 9 & 8 & \\
\hline 2 & 48 & 41 & 31 & 27 & \\
\hline $3 / 4$ & 27 & 23 & 68 & 60 & \\
\hline Granulocytopenia & & & & & $<0.01$ \\
\hline 1 & 18 & 19 & 10 & 12 & \\
\hline 2 & 22 & 23 & 8 & 10 & \\
\hline $3 / 4$ & 31 & 32 & 55 & 65 & \\
\hline Thrombocytopenia & & & & & ns \\
\hline I & 19 & 16 & 35 & 31 & \\
\hline 2 & 22 & 19 & 24 & 21 & \\
\hline $3 / 4$ & 66 & 56 & 48 & 42 & \\
\hline \multicolumn{6}{|l|}{ Transfusions } \\
\hline Red blood cells ${ }^{\mathrm{a}}$ & 66 & 56 & 61 & 50 & ns \\
\hline Platelets $^{\mathrm{a}}$ & 9 & 8 & 11 & 9 & ns \\
\hline Febrile neutropenia & 2 & 2 & 13 & II & $<0.01$ \\
\hline
\end{tabular}

aPatients receiving at least one red blood cell or platelet transfusion. $\mathrm{ns}=$ Not significant. 
Nonplatinum combination in advanced NSCLC

FM Wachters et al

Table 3 Worst nonhaematologic CTC toxicity grade per patient

\begin{tabular}{|c|c|c|c|c|c|}
\hline \multirow[b]{2}{*}{ Toxicity } & \multicolumn{2}{|c|}{ Cisplatin-gemcitabine } & \multicolumn{2}{|c|}{ Epirubicin-gemcitabine } & \multirow[b]{2}{*}{$\mathbf{P}$} \\
\hline & No. & $\%$ & No. & $\%$ & \\
\hline Bilirubin & & & & & ns \\
\hline 1 & 5 & 4 & 10 & 10 & \\
\hline 2 & 0 & 0 & 1 & 1 & \\
\hline $3 / 4$ & 0 & 0 & 2 & 2 & \\
\hline ASAT & & & & & $<0.01$ \\
\hline 1 & 31 & 27 & 43 & 40 & \\
\hline 2 & 0 & 0 & 8 & 7 & \\
\hline $3 / 4$ & 0 & 0 & 4 & 4 & \\
\hline ALAT & & & & & $<0.01$ \\
\hline 1 & 50 & 44 & 46 & 43 & \\
\hline 2 & 12 & 10 & 27 & 25 & \\
\hline $3 / 4$ & 2 & 2 & 14 & 13 & \\
\hline Creatinine & & & & & $<0.01$ \\
\hline 1 & 53 & 45 & 10 & 9 & \\
\hline 2 & 9 & 8 & 4 & 4 & \\
\hline $3 / 4$ & 0 & 0 & 0 & 0 & \\
\hline Mucositis & & & & & $<0.01$ \\
\hline 1 & 15 & 13 & 23 & 20 & \\
\hline 2 & 7 & 6 & 46 & 40 & \\
\hline $3 / 4$ & 0 & 0 & 14 & 12 & \\
\hline Nausea & & & & & $<0.01$ \\
\hline 1 & 36 & 31 & 46 & 40 & \\
\hline 2 & 51 & 44 & 27 & 24 & \\
\hline $3 / 4$ & 5 & 4 & 1 & 1 & \\
\hline Vomiting & & & & & $<0.01$ \\
\hline 1 & 37 & 32 & 28 & 25 & \\
\hline 2 & 27 & 23 & 11 & 10 & \\
\hline $3 / 4$ & 2 & 2 & । & I & \\
\hline Diarhhoea & & & & & ns \\
\hline 1 & 6 & 5 & 15 & 13 & \\
\hline 2 & 4 & 3 & 2 & 2 & \\
\hline $3 / 4$ & 3 & 3 & । & 1 & \\
\hline Fever & & & & & $<0.01$ \\
\hline 1 & 11 & 9 & 22 & 19 & \\
\hline 2 & 2 & 2 & 12 & 10 & \\
\hline $3 / 4$ & । & 1 & 3 & 3 & \\
\hline Infections & & & & & ns \\
\hline 1 & 0 & 0 & 1 & 1 & \\
\hline 2 & 2 & 2 & 3 & 3 & \\
\hline $3 / 4$ & 9 & 8 & 13 & 11 & \\
\hline Skin reactions & & & & & ns \\
\hline 1 & 9 & 8 & 14 & 12 & \\
\hline 2 & 7 & 6 & 1 & 1 & \\
\hline $3 / 4$ & । & । & 2 & 2 & \\
\hline Sensory neuropathy & & & & & $<0.01$ \\
\hline 1 & 16 & 14 & 2 & 2 & \\
\hline 2 & 7 & 6 & 1 & I & \\
\hline $3 / 4$ & 0 & 0 & 0 & 0 & \\
\hline Motoric neuropathy & & & & & ns \\
\hline I & 0 & 0 & 0 & 0 & \\
\hline 2 & 2 & 2 & 2 & 2 & \\
\hline $3 / 4$ & । & 1 & । & । & \\
\hline Anorexia & & & & & ns \\
\hline 1 & 50 & 43 & 46 & 40 & \\
\hline 2 & 27 & 23 & 38 & 33 & \\
\hline $3 / 4$ & 2 & 2 & 0 & 0 & \\
\hline Fatigue & & & & & $<0.05$ \\
\hline 1 & 41 & 35 & 22 & 19 & \\
\hline 2 & 54 & 46 & 57 & 50 & \\
\hline $3 / 4$ & 5 & 4 & 5 & 4 & \\
\hline
\end{tabular}

ns $=$ Not significant
Table 4 Number of chemotherapy cycles per patient

\begin{tabular}{lccccc}
\hline & \multicolumn{2}{c}{ Cisplatin-gemcitabine } & & \multicolumn{2}{c}{ Epirubicin-gemcitabine } \\
\cline { 2 - 3 } \cline { 5 - 6 } No. of cycles & No. & $\%$ & & No. & $\%$ \\
\hline 0 & 1 & 1 & & 2 & 2 \\
1 & 1 & 9 & & 19 & 16 \\
2 & 8 & 7 & & 11 & 9 \\
3 & 18 & 15 & & 20 & 17 \\
4 & 23 & 19 & & 20 & 17 \\
5 & 58 & 49 & & 49 & $4 \mid$ \\
Median (range) & $4(0-5)$ & & & $4(0-5)$ & \\
\hline
\end{tabular}

Table 5 Reasons for chemotherapy discontinuation

Cisplatin-gemcitabine Epirubicin-gemcitabine

Reason for discontinuation

(n)

\begin{tabular}{lrrrr} 
discontinuation & No. & $\%$ & No. & $\%$ \\
\hline Progressive disease & 18 & 15 & 24 & 20 \\
Toxicity & 21 & 18 & 27 & 22 \\
Death due to toxicity & 1 & 1 & 2 & 2 \\
Unrelated death & 2 & 2 & 3 & 3 \\
Patient's request & 7 & 6 & 5 & 4 \\
Other & 12 & 10 & 11 & 9 \\
Total discontinuations & 61 & 51 & 72 & 60
\end{tabular}

\section{Treatment}

The median (range) number of cycles per patient was $4(0-5)$ for both arms. The maximum of five cycles was completed in $58(49 \%)$ patients in the CG arm and in $49(41 \%)$ patients in the EG arm (Table 4). The reasons for treatment discontinuation between both arms were not different (Table 5).

The mean relative dose intensity for cisplatin and epirubicin was 94 and $95 \%$, respectively. The mean relative dose intensity of gemcitabine was not significantly different between both treatment arms; $89 \%$ for the EG arm and $92 \%$ for the CG arm. Cisplatin, epirubicin, and gemcitabine doses were reduced in, respectively, 6, 5 , and $12 \%$ of cycles (for gemcitabine, days 1 and 8 were taken together).

\section{Tumour response}

The overall response rate was $46 \%$ (95\% CI, 37-55) for the CG arm and $36 \%(95 \% \mathrm{CI}, 28-45)$ for the EG arm $(P=0.121)$ (Table 6). In all, 13 patients were not evaluable for tumour response due to early death from toxicity $(n=1)$, death from other causes $(n=4)$, discontinuation of treatment at patient's request after one cycle $(n=4)$, toxicity $(n=2)$, and for other reasons $(n=2)$. Three patients did not receive chemotherapy at all and were, therefore, not evaluable for response. For the analysis, these patients were considered as nonresponders. The response rates for patients with stage III $v s$ stage IV disease were 55\% (95\% CI, $41-69$ ) and $40 \%$ $(95 \% \mathrm{CI}, 28-51)$ in the CG arm, and $44 \%(95 \% \mathrm{CI}, 31-58)$ and $30 \%(95 \% \mathrm{CI}, 20-41)$ in the EG arm, respectively. All these differences were not statistically significant. The tumour response rate in patients with a performance status of 0 or 1 was $43 \%$ compared to $36 \%$ in patients with a performance status of 2 $(P=0.443)$. Elderly patients ( $\geqslant 70$ years) had a similar tumour response rate compared to younger patients. However, patients with liver metastases $(n=20)$ had a lower response rate $(15 \%)$ compared to patients without these metastases $(44 \%)(P=0.013)$. A logistic regression model with potential prognostic factors 
Table 6 Tumour response

\begin{tabular}{|c|c|c|c|c|c|}
\hline \multirow[b]{2}{*}{ Response } & \multicolumn{2}{|c|}{ Cisplatin-gemcitabine } & \multicolumn{2}{|c|}{ Epirubicin-gemcitabine } & \multirow[b]{2}{*}{$P$} \\
\hline & No. & $\%$ & No. & $\%$ & \\
\hline Complete response & 1 & 1 & 0 & 0 & \\
\hline Partial response & 54 & 45 & 44 & 36 & \\
\hline Stable disease & 40 & 34 & 37 & 31 & \\
\hline Progressive disease & 22 & 19 & 26 & 22 & \\
\hline Not assessable & 2 & 2 & 14 & 12 & \\
\hline $\begin{array}{l}\text { Overall response } \\
(95 \% \mathrm{Cl})\end{array}$ & & $46(37-55)$ & & $36(28-45)$ & 0.121 \\
\hline
\end{tabular}

(disease stage, histology, sex, age, performance status, weight loss, and liver metastases) showed that the presence of liver metastases was a significant independent negative prognostic factor for tumour response.

A total of 38 patients in the CG arm (32\%) and 39 patients in the EG arm (32\%) received second-line chemotherapy, consisting of docetaxel alone or docetaxel combined with carboplatin or irinotecan. A partial response to second-line therapy was observed in $20 \%$ of patients, without a difference between CG and EG. In all, $24 \%$ of responders and $14 \%$ of nonresponders on first-line therapy achieved a partial response to second-line therapy; this difference was also not significant. Median survival after start of second-line chemotherapy $(n=77)$ was 28 weeks (95\% CI, 22-34).

\section{Progression-free survival and overall survivals}

On August 2002, 47 patients were still alive. The median progression-free survival was not significantly different between both treatment arms; 26 (95\% CI, 20-31) vs 23 (95\% CI, 20-26) weeks for the CG and EG arm, respectively $(P=0.247)$. Progression-free survival $( \pm$ s.e.) at 6 months follow-up was $49 \%( \pm 5 \%)$ vs $40 \%( \pm 5 \%)$ for the CG and EG arm, respectively $(P=0.134)$ (Figure 1). The median overall survival was 43 (95\% CI, 30-57) weeks in the CG arm, vs 36 (95\% CI, 30-42) weeks in the EG arm, which was not different between both arms $(P=0.143)$. The 1-year survival rate $( \pm$ s.e. $)$ was $45 \%( \pm 5 \%)$ vs $35 \%( \pm 5 \%)$ in the CG and EG arm, respectively $(P=0.123)$ (Figure 2). Progression-free and overall survivals were not different in elderly patients ( $\geqslant 70$ years) when compared to younger patients.

A Cox regression model was used to find independent prognostic factors for progression-free and overall survivals. The factors disease stage, histology, sex, age, performance status, weight loss, and liver metastases were used in this model. Performance status $\leqslant 1$, absence of liver metastases, and weight loss $<5 \%$ were associated with prolonged progression-free and improved overall survivals. Stage III disease was, compared to stage IV disease, associated with longer progression-free survival.

\section{Quality of Life}

The questionnaires filled in at the patient's home at the start of treatment, after three cycles of chemotherapy, and 6 weeks after the end of treatment were returned to the datacenter by 70,47 , and $45 \%$ of patients, respectively. Between both treatment arms, no significant differences were found in global health status and functional scales (physical, role, emotional, cognitive, and social functioning), at all three moments of measurement (Table 7a). On symptom scales, differences were found in the occurrences of nausea and vomiting, that were more common in the CG arm. A sore mouth and dysphagia were more frequently noted in the EG

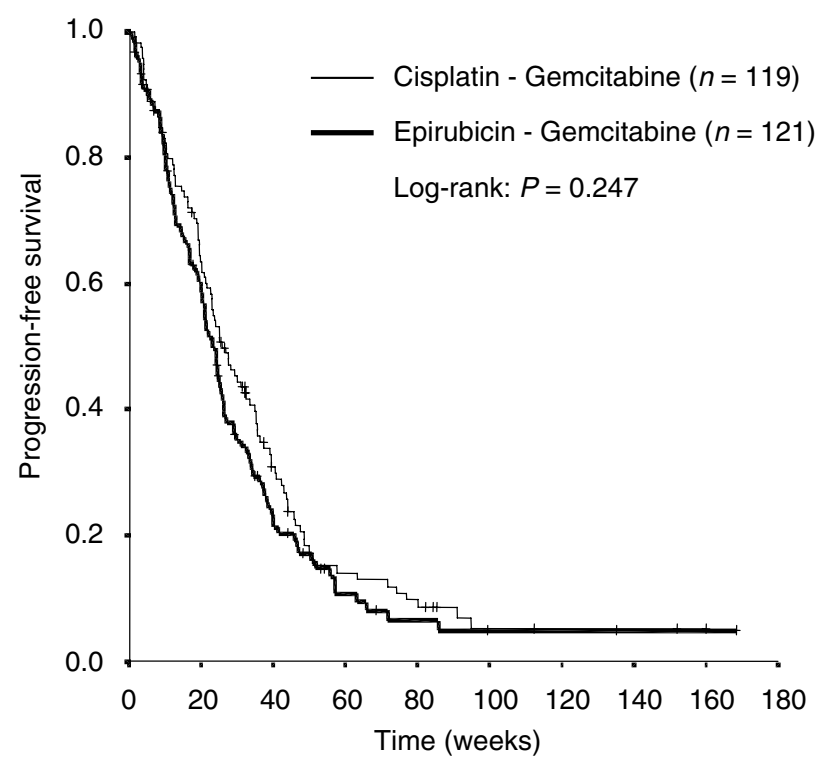

Figure I Kaplan-Meier curve for progression-free survival

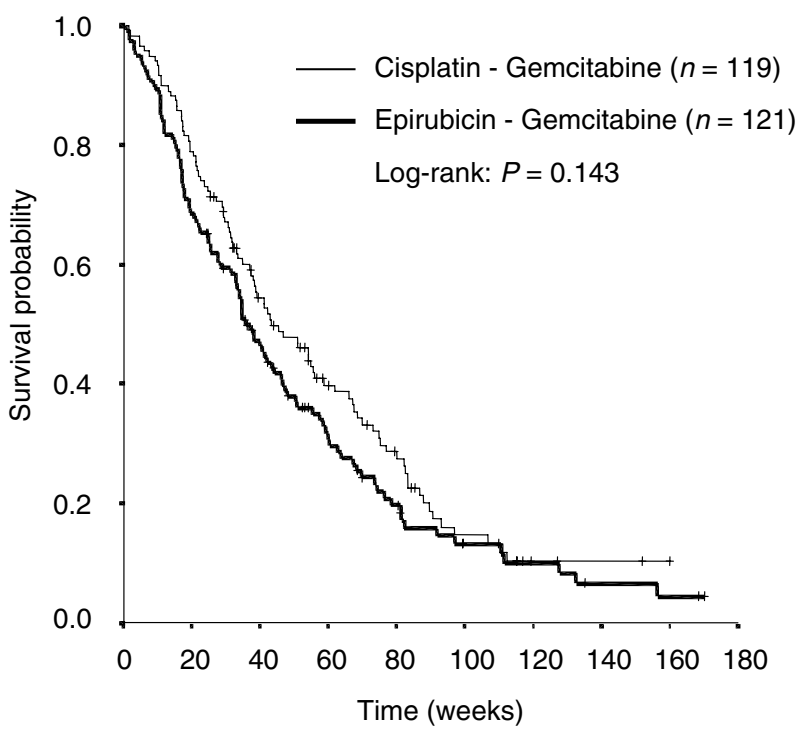

Figure 2 Kaplan-Meier curve for overall survival

arm. Fatigue did not score different between both treatment arms. A selection of scores on symptom scales from the EORTC QLQC30 and QLQ-LC13 is shown in Table 7b.

\section{DISCUSSION}

The efficacy of epirubicin and cisplatin both combined with gemcitabine is not significantly different in terms of progressionfree survival and tumour response rates. Since overall survival was not the primary end point of this trial and our power analysis was not performed to detect differences in overall survival, no definitive conclusions in terms of overall survival can be drawn although we found no significant differences in overall survival between both arms. The overall toxicity was different and more severe in the epirubicin combination. Neutropenia, febrile neutropenia, elevation of serum transaminases, mucositis, and fever occurred more frequently in the EG arm while nausea, 
Table 7 Mean quality of life scores before, during, and after treatment

\begin{tabular}{|c|c|c|c|c|c|}
\hline \multirow[b]{2}{*}{ Items } & \multicolumn{2}{|c|}{ Cisplatin-gemcitabine } & \multicolumn{2}{|c|}{ Epirubicin-gemcitabine } & \multirow[b]{2}{*}{$P$} \\
\hline & Mean & s.e. & Mean & s.e. & \\
\hline \multicolumn{6}{|l|}{ (a) } \\
\hline \multicolumn{6}{|c|}{ Global health status $^{\mathrm{a}}$} \\
\hline Before & 53.1 & 2.7 & 58.1 & 2.4 & ns \\
\hline During & 53.4 & 2.7 & 53.5 & 3.0 & ns \\
\hline After & 52.0 & 2.9 & 51.7 & 3.1 & ns \\
\hline \multicolumn{6}{|c|}{ Functional scales $^{a}$} \\
\hline \multicolumn{6}{|c|}{ Physical } \\
\hline Before & 59.1 & 3.5 & 67.3 & 2.9 & ns \\
\hline During & 56.3 & 3.6 & 51.2 & 3.8 & ns \\
\hline After & 57.0 & 3.9 & 47.1 & 3.6 & ns \\
\hline \multicolumn{6}{|l|}{ Role } \\
\hline Before & 53.2 & 3.7 & 59.3 & 3.3 & ns \\
\hline During & 48.0 & 3.8 & 37.7 & 4.2 & ns \\
\hline After & 45.9 & 3.7 & 43.0 & 4.1 & ns \\
\hline \multicolumn{6}{|l|}{ Cognitive } \\
\hline Before & 82.1 & 2.5 & 82.7 & 2.6 & ns \\
\hline During & 80.4 & 3.0 & 77.7 & 3.6 & ns \\
\hline After & 79.9 & 3.0 & 81.2 & 2.8 & ns \\
\hline \multicolumn{6}{|l|}{ Emotional } \\
\hline Before & 62.4 & 2.6 & 64.0 & 2.6 & ns \\
\hline During & 72.4 & 3.3 & 69.6 & 3.3 & ns \\
\hline After & 72.5 & 2.6 & 72.9 & 2.8 & ns \\
\hline \multicolumn{6}{|l|}{ Social } \\
\hline Before & 73.6 & 2.8 & 74.0 & 3.0 & ns \\
\hline During & 64.9 & 3.9 & 65.7 & 4.0 & ns \\
\hline After & 67.3 & 3.8 & 65.2 & 4.1 & ns \\
\hline \multicolumn{6}{|l|}{ (b) } \\
\hline \multicolumn{6}{|c|}{ Symptom scales ${ }^{b}$} \\
\hline \multicolumn{6}{|c|}{ Fatigue } \\
\hline Before & 40.2 & 3.3 & 37.3 & 3.0 & ns \\
\hline During & 49.2 & 3.2 & 56.4 & 3.7 & ns \\
\hline After & 46.5 & 3.5 & 52.0 & 3.8 & ns \\
\hline \multicolumn{6}{|c|}{ Nausea and vomiting } \\
\hline Before & 11.0 & 2.1 & 7.3 & 1.4 & ns \\
\hline During & 32.5 & 4.3 & 16.7 & 2.9 & 0.003 \\
\hline After & 31.5 & 4.5 & 12.7 & 3.5 & 0.001 \\
\hline \multicolumn{6}{|l|}{ Pain } \\
\hline Before & 25.4 & 3.1 & 27.8 & 3.1 & ns \\
\hline During & 16.7 & 3.3 & 26.2 & 4.3 & ns \\
\hline After & 22.2 & 3.9 & 32.4 & 4.4 & ns \\
\hline Appetite 10 & & & & & \\
\hline Before & 24.4 & 3.5 & 21.6 & 3.2 & ns \\
\hline During & 36.2 & 4.6 & 37.0 & 4.6 & ns \\
\hline After & 30.8 & 4.3 & 30.2 & 4.6 & ns \\
\hline Sore mouth & & & & & \\
\hline Before & 8.2 & 2.3 & 9.4 & 2.5 & ns \\
\hline During & 16.7 & 3.4 & 42.3 & 5.3 & 0.001 \\
\hline After & 9.4 & 3.2 & 35.2 & 5.6 & 0.001 \\
\hline Dysphagia & & & & & \\
\hline Before & 8.5 & 2.1 & 11.0 & 2.5 & ns \\
\hline During & 13.6 & 3.4 & 31.4 & 5.0 & 0.003 \\
\hline After & 9.4 & 2.9 & 27.2 & 4.8 & 0.002 \\
\hline Peripheral & & & & & \\
\hline Before & 11.0 & 2.4 & 7.1 & 1.9 & ns \\
\hline During & 16.4 & 3.3 & 14.0 & 3.2 & ns \\
\hline After & 19.5 & 4.0 & 12.6 & 3.0 & ns \\
\hline
\end{tabular}

${ }^{a}$ Scores range from 0 to 100 , with a higher score representing a higher level of functioning.

${ }^{\mathrm{b}} \mathrm{S}$ cores range from 0 to 100 , with a higher score representing a greater degree of symptoms.

ns $=$ Not significant vomiting, nephrotoxicity, and sensory neuropathy were more common in the CG arm. The decline in LVEF after treatment, especially grade 1, was more evident in the EG arm, but was not associated with clinical signs of heart failure during follow-up. In line with CTC toxicity evaluation, the symptom scales of EORTC questionnaires showed a different spectrum of toxicity in both arms. The global health status and scores on functional scales were similar in both arms in all three moments of measurement, although the number of patients who returned their questionnaires was limited and therefore no firm conclusions can be drawn.

Although in this trial efficacy was similar in both arms in terms of progression-free survival, overall survival, and response rate, this trial failed to show benefits in terms of less toxicity for the nonplatinum-based regimen. Other trials showed similar response rates and survival, and less toxicity in patients treated with nonplatinum-based schedules compared to platinum-containing combinations (Gatzemeier et al, 1991; Gridelli et al, 1996; Georgoulias et al, 2001; Sculier et al, 2002). A recently published study compared four platinum-based regimens for advanced NSCLC (cisplatin with either paclitaxel, gemcitabine, or docetaxel, and carboplatin with paclitaxel), and showed no difference in survival (the median survival was 7.9 months for all patients) and response rate (19\% for all patients). However, progression-free survival was longer in the group of patients who received cisplatin and gemcitabine (4.2 months). On the other hand, treatment with cisplatin and gemcitabine was associated with more renal toxicity (Schiller et al, 2002). Recently, Rosell et al (2002) compared two platinum-based regimens and showed that a cisplatin-based therapy was associated with a significantly longer median survival. However, in our trial, response rates and survival were similar in both arms, but the nonplatinum-containing regimen had a less favourable toxicity profile. Based on these data, we conclude that a platinum-based combination therapy remains the standard treatment for advanced NSCLC.

A performance status of 2, liver metastases, and weight loss of more than $5 \%$ were associated with a worse survival. An unfavourable survival outcome for patients with a poor performance status has also been reported in other studies (Comella et al, 1996; Cullen et al, 1999; Le Chevalier et al, 2001; Sweeney et al, 2001). Whether chemotherapy in patients with a performance status of 2 should be advocated is still a matter of debate. For these patients, a new therapeutic approach, for example, with biologicals with hardly any toxicity, may be a more attractive treatment option. Further trials are required to investigate these modalities.

In the 28 elderly patients $(\geqslant 70$ years $)$ included in this trial toxicity (except thrombocytopenia), the tumour response rate, progression-free and overall survivals were not different compared to younger patients. However, in contrast to the fact that $35-43 \%$ of all lung cancers arise beyond the age of 70 years (Fry et al, 1999), in this trial only $12 \%$ of patients were over 70 years of age. It is possible that we cannot demonstrate differences between elderly and younger patients due to exclusion of elderly patients with a poor performance status or comorbidity. Generally, elderly patients are thought to be less able to tolerate polychemotherapy (Frasci, 2002). However, to date prospective randomised trials on the beneficial role of platinum-based chemotherapy in elderly NSCLC patients are not available (Frasci, 2002).

Shepherd et al (2000) have shown that second-line treatment with single-agent docetaxel, compared to best supportive care, is associated with prolongation of survival. The tumour response rate of single-agent docetaxel in this trial was $7.1 \%$. However, in our study the observed tumour response rate after predominantly docetaxel-containing doublets as second-line chemotherapy regimens was $20 \%$, suggesting that a combination regimen may be 
more effective than a single agent one. Other trials on second-line chemotherapy in NSCLC, reviewed by Huisman et al (2000), also report higher response rates.

In conclusion, we found no differences in efficacy and global QOL between cisplatin and epirubicin, both in combination with gemcitabine as first-line treatment for advanced NSCLC. However, the observed differences in toxicity profile are in favour of cisplatin. Therefore, a platinum-based combina- tion regimen remains the recommended treatment for advanced NSCLC.

\section{ACKNOWLEDGEMENT}

This study was supported by Eli Lilly, Nieuwegein, The Netherlands.

\section{REFERENCES}

Aaronson NK, Ahmedzai S, Bergman B, Bullinger M, Cull A, Duez NJ, Filiberti A, Flechtner H, Fleishman SB, De Haes JC (1993) The European Organization for Research and Treatment of Cancer QLQ-C30: a qualityof-life instrument for use in international clinical trials in oncology. $J$ Natl Cancer Inst 85: 365-376

American Society of Clinical Oncology (1997) Clinical practice guidelines for the treatment of unresectable non-small-cell lung cancer. Adopted on May 16, 1997 by the American Society of Clinical Oncology. J Clin Oncol 15: $2996-3018$

Anderson H, Lund B, Bach F, Thatcher N, Walling J, Hansen HH (1994) Single-agent activity of weekly gemcitabine in advanced non-small-cell lung cancer: a phase II study. J Clin Oncol 12: 1821-1826

Bergman B, Aaronson NK, Ahmedzai S, Kaasa S, Sullivan M (1994) The EORTC QLQ-LC13: a modular supplement to the EORTC core quality of life questionnaire (QLQ-C30) for use in lung cancer clinical trials. EORTC Study Group on Quality of life. Eur J Cancer 30A: 635-642

Bunn Jr PA, Kelly K (1998) New chemotherapeutic agents prolong survival and improve quality of life in non-small cell lung cancer: a review of the literature and future directions. Clin Cancer Res 4: 1087-1100

Cardenal F, Lopez-Cabrerizo MP, Anton A, Alberola V, Massuti B, Carrato A, Barneto I, Lomas M, Garcia M, Lianes P, Montalar J, Vadell C, Gonzalez-Larriba JL, Nguyen B, Artal A, Rosell R (1999) Randomized phase III study of gemcitabine-cisplatin versus etoposide-cisplatin in the treatment of locally advanced or metastatic non-small-cell lung cancer. J Clin Oncol 17: $12-18$

Cockcroft DW, Gault MH (1976) Prediction of creatinine clearance from serum creatinine. Nephron 16: $31-41$

Comella P, Frasci G, De Cataldis G, Panza N, Cioffi R, Curcio C, Belli M, Bianco A, Ianniello G, Maiorino L, Della VM, Perchard J, Comella G (1996) Cisplatin/carboplatin+etoposide+vinorelbine in advanced nonsmall-cell lung cancer: a multicentre randomised trial. Gruppo Oncologico Campano. Br J Cancer 74: 1805-1811

Comella P, Frasci G, Panza N, Manzione L, De Cataldis G, Cioffi R, Maiorino L, Micillo E, Lorusso V, Di Rienzo G, Filippelli G, Lamberti A Natale M, Bilancia D, Nicolella G, Di Nota A, Comella G (2000) Randomized trial comparing cisplatin, gemcitabine, and vinorelbine with either cisplatin and gemcitabine or cisplatin and vinorelbine in advanced non-small-cell lung cancer: interim analysis of a phase III trial of the Southern Italy Cooperative Oncology Group. J Clin Oncol 18: 1451 - 1457

Crino L, Scagliotti GV, Ricci S, De Marinis F, Rinaldi M, Gridelli C, Ceribelli A, Bianco R, Marangolo M, Di Costanzo F, Sassi M, Barni S, Ravaioli A, Adamo V, Portalone L, Cruciani G, Masotti A, Ferrara G, Gozzelino F, Tonato M (1999) Gemcitabine and cisplatin versus mitomycin, ifosfamide, and cisplatin in advanced non-small-cell lung cancer: a randomized phase III study of the Italian Lung Cancer Project. J Clin Oncol 17: $3522-3530$

Cullen MH, Billingham LJ, Woodroffe CM, Chetiyawardana AD, Gower NH, Joshi R, Ferry DR, Rudd RM, Spiro SG, Cook JE, Trask C, Bessell E, Connolly CK, Tobias J, Souhami RL (1999) Mitomycin, ifosfamide, and cisplatin in unresectable non-small-cell lung cancer: effects on survival and quality of life. J Clin Oncol 17: 3188-3194

Feld R, Wierzbicki R, Walde PL, Shepherd FA, Evans WK, Gupta S, Shannon P, Lassus M (1992) Phase I-II study of high-dose epirubicin in advanced non-small-cell lung cancer. J Clin Oncol 10: 297-303

Frasci G (2002) Chemotherapy of lung cancer in the elderly. Crit Rev Oncol Hematol 41: 349-361

Fry WA, Phillips JL, Menck HR (1999) Ten-year survey of lung cancer treatment and survival in hospitals in the United States: a national cancer data base report. Cancer 86: $1867-1876$

Gatzemeier U, Heckmayr M, Hossfeld DK, Kaukel E, Koschel G, Neuhauss $\mathrm{R}$ (1991) A randomized trial with mitomycin $\mathrm{C} /$ ifosfamide versus mitomycin C/vindesine versus cisplatin/etoposide in advanced nonsmall-cell lung cancer. Am J Clin Oncol 14: 405-411

Gatzemeier U, Shepherd FA, Le Chevalier T, Weynants P, Cottier B, Groen HJM, Rosso R, Mattson K, Cortes-Funes H, Tonato M, Burkes RL, Gottfried M, Voi M (1996) Activity of gemcitabine in patients with nonsmall-cell lung cancer: a multicentre, extended phase II study. Eur J Cancer 32A: $243-248$

Georgoulias V, Papadakis E, Alexopoulos A, Tsiafaki X, Rapti A, Veslemes M, Palamidas P, Vlachonikolis I (2001) Platinum-based and nonplatinum-based chemotherapy in advanced non-small-cell lung cancer: a randomised multicentre trial. Lancet 357: 1478-1484

Gridelli C, Perrone F, Palmeri S, D’Aprile M, Cognetti F, Rossi A, Gebbia V, Pepe R, Veltri E, Airoma G, Russo A, Incoronato P, Scinto AF, Palazzolo G, Natali M, Leonardi V, Gallo C, De Placido S, Bianco AR (1996) Mitomycin C plus vindesine plus etoposide (MEV) versus mitomycin C plus vindesine plus cisplatin (MVP) in stage IV non-small-cell lung cancer: a phase III multicentre randomised trial. The 'Gruppo Oncologico Centro-Sud-Isole' (G.O.C.S.I.). Ann Oncol 7: 821-826

Halme M, Jekunen A, Tamminen K, Mattson K (1997) Phase II study of weekly gemcitabine in advanced non-small cell lung cancer. Respir Med 91: $423-426$

Huisman C, Smit EF, Giaccone G, Postmus PE (2000) Second-line chemotherapy in relapsing or refractory non-small-cell lung cancer: a review. J Clin Oncol 18: $3722-3730$

Kosmidis P, Mylonakis N, Nicolaides C, Kalophonos C, Samantas E, Boukovinas J, Fountzilas G, Skarlos D, Economopoulos T, Tsavdaridis D, Papakostas P, Bacoyiannis C, Dimopoulos M (2002) Paclitaxel plus carboplatin versus gemcitabine plus paclitaxel in advanced non-smallcell lung cancer: a phase III randomized trial. J Clin Oncol 20: 3578 - 3585

Le Chevalier T, Brisgand D, Soria JC, Douillard JY, Pujol JL, Ruffie P, Aberola V, Cigolari S (2001) Long term analysis of survival in the European randomized trial comparing vinorelbine/cisplatin to vindesine/cisplatin and vinorelbine alone in advanced non-small cell lung cancer. Oncologist 6(suppl 1): 8-11

Non-small Cell Lung Cancer Collaborative Group (1995) Chemotherapy in non-small cell lung cancer: a meta-analysis using updated data on individual patients from 52 randomised clinical trials. BMJ 311: 899-909

Perng RP, Chen YM, Ming-Liu J, Tsai CM, Lin WC, Yang KY, Whang-Peng J (1997) Gemcitabine versus the combination of cisplatin and etoposide in patients with inoperable non-small-cell lung cancer in a phase II randomized study. J Clin Oncol 15: 2097-2102

Rosell R, Gatzemeier U, Betticher DC, Keppler U, Macha HN, Pirker R, Berthet P, Breau JL, Lianes P, Nicholson M, Ardizzoni A, Chemaissani A, Bogaerts J, Gallant G (2002) Phase III randomised trial comparing paclitaxel/carboplatin with paclitaxel/cisplatin in patients with advanced non-small-cell lung cancer: a cooperative multinational trial. Ann Oncol 13: $1539-1549$

Sandler AB, Nemunaitis J, Denham C, Von Pawel J, Cormier Y, Gatzemeier U, Mattson K, Manegold C, Palmer MC, Gregor A, Nguyen B, Niyikiza C, Einhorn LH (2000) Phase III trial of gemcitabine plus cisplatin versus cisplatin alone in patients with locally advanced or metastatic non-smallcell lung cancer. J Clin Oncol 18: $122-130$

Schiller JH, Harrington D, Belani CP, Langer C, Sandler A, Krook J, Zhu J, Johnson DH (2002) Comparison of four chemotherapy regimens for advanced non-small-cell lung cancer. $N$ Engl J Med 346: $92-98$

Sculier JP, Lafitte JJ, Lecomte J, Berghmans T, Thiriaux J, Florin MC, Efremidis A, Alexopoulos CG, Recloux P, Ninane V, Mommen P, Paesmans M, Klastersky J (2002) A three-arm phase III randomised trial comparing combinations of platinum derivatives, ifosfamide and/or gemcitabine in stage IV non-small-cell lung cancer. Ann Oncol 13: $874-882$ 
Shepherd FA, Dancey J, Ramlau R, Mattson K, Gralla R, O'Rourke M, Levitan N, Gressot L, Vincent M, Burkes R, Coughlin S, Kim Y, Berille J (2000) Prospective randomized trial of docetaxel versus best supportive care in patients with non-small-cell lung cancer previously treated with platinum-based chemotherapy. J Clin Oncol 18: 2095-2103

Smit EF, Berendsen HH, Piers DA, Smeets J, Riva A, Postmus PE (1992) A phase II study of high dose epirubicin in unresectable non small cell lung cancer. Br J Cancer 65: 405-408

Sweeney CJ, Zhu J, Sandler AB, Schiller J, Belani CP, Langer C, Krook J, Harrington D, Johnson DH (2001) Outcome of patients with a performance status of 2 in Eastern Cooperative Oncology Group Study E1594: a phase II trial in patients with metastatic non-small-cell lung carcinoma. Cancer 92: 2639-2647

Takada M, Negoro S, Kudo S, Furuse K, Nishikawa H, Takada Y, Kamei T, Niitani H, Fukuoka M (1998) Activity of gemcitabine in non-small-cell lung cancer: results of the Japan gemcitabine group (A) phase II study. Cancer Chemother Pharmacol 41: 217-222

Ten Bokkel Huinink WW, Bergman B, Chemaissani A, Dornoff W, Drings

P, Kellokumpu-Lehtinen PL, Liippo K, Mattson K, Von Pawel J, Ricci S,
Sederholm C, Stahel RA, Wagenius G, Walree NV, Manegold C (1999) Single-agent gemcitabine: an active and better tolerated alternative to standard cisplatin-based chemotherapy in locally advanced or metastatic non-small cell lung cancer. Lung Cancer 26: 85-94

Van Putten JWG, Eppinga P, Erjavec Z, De Leede GPJ, Nabers J, Smeets JB, Th SD, Groen HJM (2000) Activity of high-dose epirubicin combined with gemcitabine in advanced non-small-cell lung cancer: a multicenter phase I and II study. Br J Cancer 82: 806-811

Wils J, Utama I, Sala L, Smeets J, Riva A (1990) Phase II study of high-dose epirubicin in non-small cell lung cancer. Eur J Cancer 26: 1140 - 1141

World Health Organisation (1979) WHO Handbook for reporting results of cancer treatment. Geneva, Switzerland

Yokoyama A, Nakai Y, Yoneda S, Kurita Y, Niitani H (1997) Activity of gemcitabine in the treatment of patients with non-small-cell lung cancer: a multicenter phase II study. Anticancer Drugs 8: 574-581

Zatloukal P, Kanitz E, Magyar P, Jassem J, Krzakowski M, Pawlicki M, Petruzelka L, Chovan L, Pesek M, Janko C, Krejcy K (1998) Gemcitabine in locally advanced and metastatic non-small cell lung cancer: the Central European phase II study. Lung Cancer 22: 243-250 